Claremont Colleges

Scholarship@Claremont

$1-1-2007$

\title{
Spatial and Temporal Expression of Vegetation and Atmospheric Variability from Stable Carbon and Nitrogen Isotope Analysis of Bat Guano in the Southern United States
}

\author{
Christopher M. Wurster \\ University of St. Andrews \\ Donald A. McFarlane \\ Claremont McKenna College; Pitzer College; Scripps College \\ Michael I. Bird \\ University of St. Andrews
}

\section{Recommended Citation}

Wurster, C. M., McFarlane, D. A., and Bird, M. I. (2007). "Spatial and temporal expression of vegetation and atmospheric variability from stable carbon and nitrogen isotope analysis of bat guano in the southern United States." Geochimica et Cosmochimica Acta 71: 3302-3310. 
Provided for non-commercial research and educational use only. Not for reproduction or distribution or commercial use.

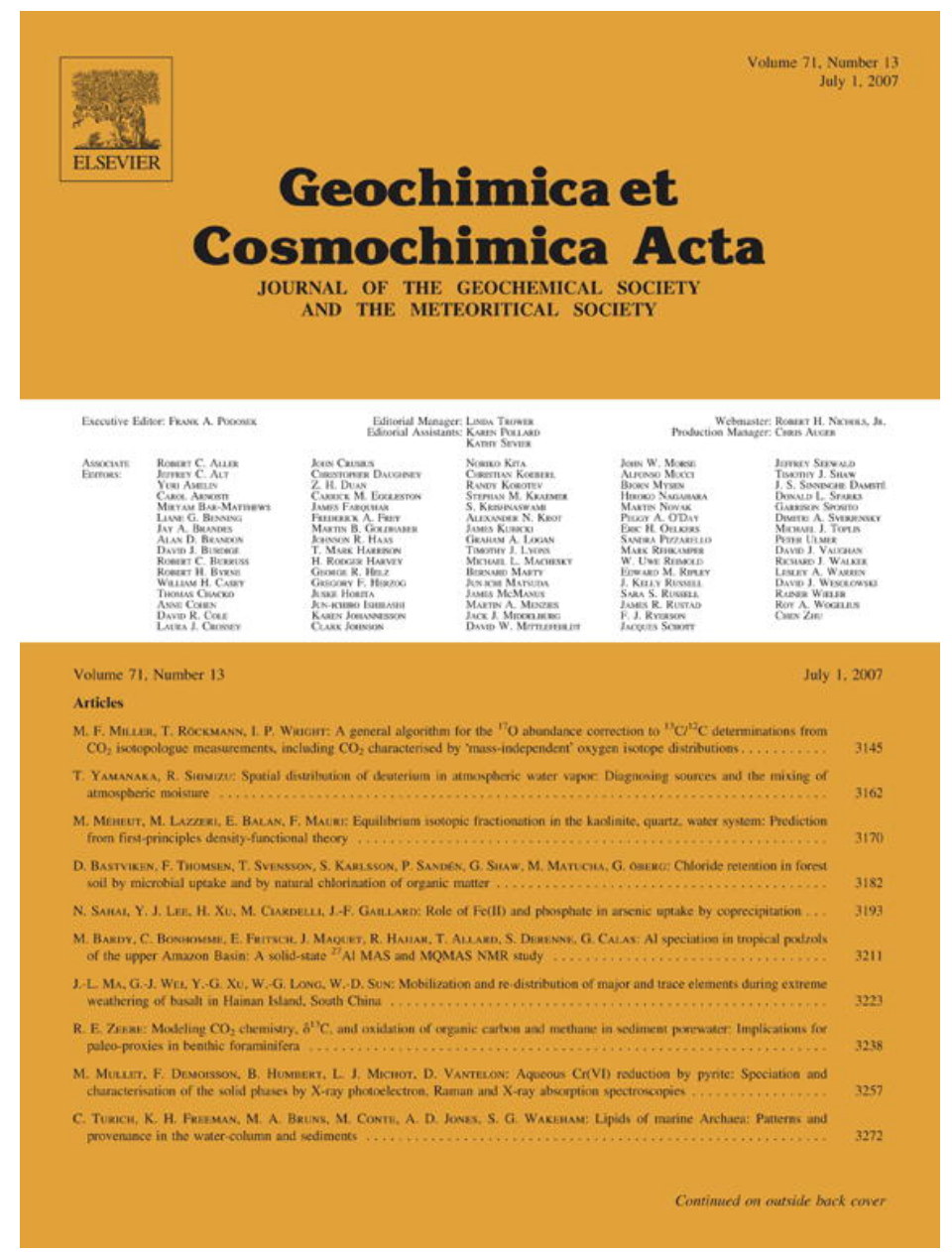

This article was originally published in a journal published by Elsevier, and the attached copy is provided by Elsevier for the author's benefit and for the benefit of the author's institution, for non-commercial research and educational use including without limitation use in instruction at your institution, sending it to specific colleagues that you know, and providing a copy to your institution's administrator.

All other uses, reproduction and distribution, including without limitation commercial reprints, selling or licensing copies or access,

or posting on open internet sites, your personal or institution's website or repository, are prohibited. For exceptions, permission may be sought for such use through Elsevier's permissions site at:

http://www.elsevier.com/locate/permissionusematerial 


\title{
Spatial and temporal expression of vegetation and atmospheric variability from stable carbon and nitrogen isotope analysis of bat guano in the southern United States
}

\author{
Christopher M. Wurster ${ }^{\mathrm{a}, *}$, Donald A. McFarlane ${ }^{\mathrm{b}}$, Michael I. Bird ${ }^{\mathrm{a}}$ \\ a School of Geography and Geosciences, University of St. Andrews, St. Andrews, Fife KY16 9AL, UK \\ b W.M. Keck Science Center, The Claremont Colleges, 925 North Mills Avenue, Claremont, CA 91711, USA
}

Received 4 January 2007; accepted in revised form 2 May 2007; available online 8 May 2007

\begin{abstract}
Stable isotopes of faeces contain information related to the animals feeding ecology. The use of stable isotope values from subfossil faeces as a palaeoenvironmental indicator depends on how faithfully the animal records their local environment. Here we present insectivorous bat guano $\delta^{13} \mathrm{C}$ and $\delta^{15} \mathrm{~N}$ values from a precipitation gradient across the southern United States and northern Mexico to compare with local vegetation and climate. We find $\delta^{13} \mathrm{C}$ values to be an excellent predictor of expected $\mathrm{C}_{4} / \mathrm{CAM}$ vegetation, indicating that the bats are non-selective in their diet. Moreover, we find bat guano $\delta^{13} \mathrm{C}$ values to be strongly correlated with summer precipitation amount and winter precipitation ratio. We also find evidence for a significant relationship with mean annual temperature. In general, we do not find $\delta^{15} \mathrm{~N}$ values to be related to any parameters along the climatic gradient we examined. Additionally, we measured $\delta^{13} \mathrm{C}$ and $\delta^{15} \mathrm{~N}$ values of bulk guano deposited annually from 1968 to 1987 in a varved guano deposit at Eagle Creek Cave, Arizona. Neither $\delta^{13} \mathrm{C}$ nor $\delta^{15} \mathrm{~N}$ values were significantly related to various local meteorological variables; however, we found $\delta^{13} \mathrm{C}$ values of guano to be significantly related to drought and to the North American Monsoon indicating bat guano $\delta^{13} \mathrm{C}$ values preserve an interpretable record of large-scale atmospheric variability.
\end{abstract}

(C) 2007 Elsevier Ltd. All rights reserved.

\section{INTRODUCTION}

Variability of atmospheric and oceanic circulations results in an array of modes in the global climate system (Wang and Schimel, 2003), and these modes can switch abruptly in response to external perturbations (e.g., deMenocal et al., 2000). The El Niño-Southern Oscillation (ENSO) is one such important large-scale climate disturbance occurring irregularly at intervals of 3-12 years (Quinn et al., 1987). Moreover, ENSO climate anomalies are superimposed over more regionally characteristic large-scale atmospheric patterns such as regional monsoon

\footnotetext{
* Corresponding author. Fax: +44 1334463949.

E-mail address: christopher.wurster@st-andrews.ac.uk (C.M. Wurster).
}

systems. Any change in the Earth's climate immediately impacts global ecosystem health and services thereby affecting socioeconomic systems (Wang and Schimel, 2003). In order for humankind to mitigate and adapt to these impacts, it is essential to understand how these modes have operated in the past, and to assess the risk of future abrupt changes in the Earth System.

However, temporal-spatial patterns in large-scale climate variability remain poorly known, particularly in interior continental regions. Determining ENSO or monsoonal variability requires high-resolution records that capture millennial-to-annual climate information over large spatial scales. Proxy sedimentary records therefore need to have long-term deposition at high rates, and be amenable to current dating techniques. In semi-arid regions, such archives are lacking because the climate does not favour the preservation of aquatic sediments (Des 
Marais et al., 1980). Nonetheless, drylands characterize $40 \%$ of the global landmass, and are growing centres of population in a marginal habitat acutely sensitive to changes in climate (WRI, 2002).

A potentially powerful but unexploited archive can be found in guano deposits left in roosts of desert bats. The Mexican free-tailed bat (Tadarida brasiliensis) migrates each summer from Mexico to Arizona and New Mexico (Altenbach and Petit, 1972). Bat caves are sometimes known to contain large deposits of laminated guano that have accumulated for thousands of years (Des Marais et al., 1980; Mizutani et al., 1992a,b). Moreover, the migration patterns of bats sometimes result in annual laminations (Altenbach and Petit, 1972; Mizutani et al., 1992a). T. brasiliensis is a general insectivore whose guano is preserved due to the desiccating nature of desert cave environments (Mizutani et al., 1992a). Stable isotope values of guano should reflect dietary sources of the bat, and archive environmental and climatic information.

Various physiological pathways of carbon fixation in plants yield differing $\delta^{13} \mathrm{C}$ values (e.g., Ehleringer et al., 1997). Through non-specific insect predation, $\delta^{13} \mathrm{C}$ values of bats should reflect the relative abundance of the three major physiological pathways in plants: $\mathrm{C}_{3}, \mathrm{C}_{4}$, and CAM. $\delta^{13} \mathrm{C}$ values of $\mathrm{C}_{3}$ plants are lower than $\mathrm{C}_{4}$ or $\mathrm{CAM}$ vegetation due to different enzymatic discriminations of the heavy isotope through the carbon fixing pathways. Local environmental conditions determine the photosynthetic efficiencies of $\mathrm{C}_{3}$ vegetation, and the competitive success of a particular photosynthetic mechanism (Ehleringer, 1978; Ehleringer et al., 1997). At higher temperatures and lower $\mathrm{CO}_{2}$ partial pressures, the photosynthetic efficiency of $\mathrm{C}_{3}$ plants is reduced, and at a particular threshold temperature for a given atmospheric $\mathrm{CO}_{2}$ partial pressure, $\mathrm{C}_{4}$ will have a competitive advantage (Ehleringer et al., 1997). Although effective moisture appears to play a secondary role in determining competitive advantage, $\mathrm{C}_{4}$ grasses are able to use summer moisture resources more effectively (Lin et al., 1996; Schwinning et al., 2002, 2003), but in very dry regions, $\mathrm{C}_{3}$ shrubs that can tap into deep groundwater sources replace $\mathrm{C}_{4}$ grasses (Paruelo and Lauenroth, 1996; Collatz et al., 1998). CAM plants are also favoured under hot and dry conditions, but are heterogeneously distributed and can be important contributors in some locations (e.g., Aide and Van Auken, 1985; Paruelo and Lauenroth, 1996).

Herein, we present $\delta^{13} \mathrm{C}$ and $\delta^{15} \mathrm{~N}$ values of $T$. brasiliensis guano across the southern United States and Northwest Mexico to compare with local vegetation and climate patterns to test whether these stable isotope values can be used to track nutrient flow and environments in the past; particularly for areas where such records are lacking. We also present $\delta^{13} \mathrm{C}$ and $\delta^{15} \mathrm{~N}$ values from an annually laminated guano sequence taken from Eagle Creek Cave, Arizona to determine if inter-annual meteorological variability is recorded; particularly focusing on several large-scale atmospheric variability measures: Southern Oscillation Index (SOI), Palmer Drought Severity Index (PDSI) (Palmer, 1965), and the North American Monsoon System Index (NAMSI) (Li and Zeng, 2002, 2005).

\section{MATERIALS AND METHODS}

\subsection{Study area and field collection}

Tadarida brasiliensis can be found in large maternity roosts in the southwest United States and in smaller numbers across a broad climatic gradient, that extends into the eastern US (Wilkins, 1989). Whereas Florida is sub-tropical and receives abundant precipitation year round, the southwest United States is largely arid, predominately due to an orographic rainshadow effect as major winter storm tracks derived from the west cross major mountain belts (West, 1983). The North American Monsoon System (NAMS), affecting Arizona and New Mexico, is a seasonal change in atmospheric circulation expressed as a pronounced increase in summer precipitation after a hyperarid spring (Adams and Comrie, 1997; Wright et al., 2001). Large-scale circulation patterns are forced by differential heating of the North American continent in the summer resulting in the development of a thermal low over the southwest United States, and northward displacement of the Pacific and Bermuda highs (Adams and Comrie, 1997; Sheppard et al., 2002). Large-scale circulation patterns result in a longitudinal precipitation gradient westward. Texas and New Mexico receives the bulk of precipitation during the summer, Arizona's precipitation is largely bimodal (with winter precipitation increasing in importance toward the north), and California's precipitation comes dominantly during the winter. The climate of the southwestern USA is also related to ENSO (El NiñoSouthern Oscillation) variability, with strong El Niño events being associated with anomalously high precipitation amounts in winter (Sheppard et al., 2002) resulting in distinct changes in vegetation (Stapp et al., 1999; Smith et al., 2002).

Tadarida brasiliensis bat guano was collected at various sites across the southern United States and Northwest Mexico (Table 1 and Fig. 1). Most guano samples were collected in the fall/winter 2002-2004, with a few additional samples taken at other times. Approximately $2 \mathrm{~g}$ of fresh guano was collected by scooping the surface under a roost (bridges or just outside caves) and placed in whirl-pak bags. In February 1988, a guano profile approximately $2-\mathrm{m}$ depth was excavated from Eagle Creek Cave that revealed laminations, each couplet was approximately $15-\mathrm{cm}$ thick. Prior studies have shown that each couplet represent one year due to the morphology of the cave coupled with a unique cave ecology (Altenbach and Petit, 1972; Mizutani et al., 1992a). During late spring, the bats arrive at Eagle Creek Cave, and within days the bat population is at its maximum, leading to their guano accumulating on the cave floor as pellets. By midsummer, Dermestid beetles have hatched and increase in population during the summer. The beetles feed mostly on dead bats and some guano. In early October, the bats migrate to Mexico, and the beetles begin to feed on the surface of the guano leaving a light coloured fine textured band. By December the beetles have died, leaving eggs to hatch the following summer (McFarlane and Keeler, 1990). After excavation, 10-20 g of guano from each couplet was collected down the profile by scooping 
Table 1

Sample locations, stable isotope values, and weight percents of bat guano

\begin{tabular}{|c|c|c|c|c|c|c|}
\hline Sample description & Date $^{\mathrm{d}}$ & $\delta^{13} \mathrm{C} \%$ VPDB ${ }^{\mathrm{e}}$ & $\delta^{15} \mathrm{~N} \% \circ \mathrm{AIR}^{\mathrm{e}}$ & $\% \mathrm{C}$ & $\% \mathrm{~N}$ & $\mathrm{C}: \mathrm{N}$ \\
\hline \multicolumn{7}{|l|}{ Congress Bridge $^{a}$} \\
\hline $30.27 \mathrm{~N}, 97.74 \mathrm{~W}$ & 2003 & $-20.4 \pm 0.1$ & $5.5 \pm 0.2$ & 47.8 & 10.2 & 4.7 \\
\hline \multicolumn{7}{|l|}{ Bracken Cave $^{\mathrm{a}}$} \\
\hline $29.60 \mathrm{~N} 98.32 \mathrm{~W}$ & 2004 & $-19.5 \pm 0.1$ & $4.4 \pm 0.0$ & 50.1 & 10.6 & 4.7 \\
\hline \multicolumn{7}{|l|}{ Fresno Creek $^{\mathrm{a}}$} \\
\hline $29.22 \mathrm{~N} 103.84 \mathrm{~W}$ & 2002 & $-17.8 \pm 0.3$ & $4.4 \pm 0.3$ & 49.6 & 9.9 & 5.0 \\
\hline \multicolumn{7}{|l|}{ Cueva del Tigre $^{\mathrm{a}}$} \\
\hline $29.57 \mathrm{~N} 110.82 \mathrm{~W}$ & 1998 & $-22.9 \pm 0.1$ & $8.3 \pm 0.0$ & 25.3 & 3.6 & 7.0 \\
\hline \multicolumn{7}{|l|}{ Bat Cave } \\
\hline $36.04 \mathrm{~N} 113.80 \mathrm{~W}$ & 2002 & $-23.8 \pm 0.1$ & $7.1 \pm 0.3$ & 47.5 & 10.7 & 4.4 \\
\hline$-^{\mathrm{a}}$ & 1994 & $-24.1 \pm 0.2$ & $8.0 \pm 0.4$ & 48.6 & 10.7 & 4.6 \\
\hline$-^{\mathrm{b}}$ & 1998 & -24.4 & & & & \\
\hline \multicolumn{7}{|l|}{ Yuma Mine $^{a}$} \\
\hline $32.83 \mathrm{~N} 114.50 \mathrm{~W}$ & 2003 & $-27.4 \pm 0.3$ & $6.4 \pm 0.2$ & 48.2 & 9.8 & 4.9 \\
\hline \multicolumn{7}{|l|}{ Topanga Canyon ${ }^{\mathrm{a}}$} \\
\hline $34.08 \mathrm{~N} 118.56 \mathrm{~W}$ & 2003 & $-24.9 \pm 0.2$ & $4.4 \pm 0.1$ & 51.4 & 10.6 & 4.9 \\
\hline \multicolumn{7}{|l|}{ Gainseville $^{\mathrm{a}}$} \\
\hline $29.65 \mathrm{~N} 82.32 \mathrm{~W}$ & 2003 & $-24.3 \pm 0.0$ & $3.7 \pm 0.0$ & 43.8 & 8.9 & 4.9 \\
\hline \multicolumn{7}{|l|}{ Carlsbad Caverns $^{\mathrm{b}}$} \\
\hline $32.18 \mathrm{~N} 104.44 \mathrm{~W}$ & & -21.6 & 12.7 & & & \\
\hline$-^{\mathrm{c}}$ & & -20.1 & & & & \\
\hline \multicolumn{7}{|c|}{ Coon Springs Cave ${ }^{\mathrm{b}, \mathrm{Msp}}$} \\
\hline $33.05 \mathrm{~N} 109.32 \mathrm{~W}$ & & -23.4 & 0. & & & \\
\hline \multicolumn{7}{|l|}{ Roosevelt Mine $\mathrm{b}^{\mathrm{b}, \mathrm{Mc}}$} \\
\hline $33.26 \mathrm{~N} 116.41 \mathrm{~W}$ & & -24.9 & & & & \\
\hline \multicolumn{7}{|l|}{ California Mine ${ }^{\mathrm{b}, \mathrm{Mv}}$} \\
\hline $33.26 \mathrm{~N} 116.41 \mathrm{~W}$ & & -25.5 & 9.6 & & & \\
\hline \multicolumn{7}{|l|}{ Eagle Creek Cave $^{a}$} \\
\hline \multirow[t]{21}{*}{$33.05 \mathrm{~N} 109.32 \mathrm{~W}$} & Avg. & -21.8 & 6.0 & & & \\
\hline & 1987 & $-19.6 \pm 0.1$ & $6.4 \pm 0.2$ & 47.9 & 10.3 & 4.7 \\
\hline & 1986 & $-20.9 \pm 0.1$ & $6.0 \pm 0.3$ & 46.1 & 10.5 & 4.4 \\
\hline & 1985 & $-20.5 \pm 0.1$ & $5.9 \pm 0.1$ & 49.6 & 11.3 & 4.4 \\
\hline & 1984 & $-21.5 \pm 0.0$ & $5.7 \pm 0.2$ & 49.6 & 10.1 & 4.9 \\
\hline & 1983 & $-23.0 \pm 0.2$ & $5.8 \pm 0.3$ & 48.1 & 10.4 & 4.6 \\
\hline & 1982 & $-22.5 \pm 0.2$ & $6.0 \pm 0.2$ & 47.4 & 10.2 & 4.6 \\
\hline & 1981 & $-22.3 \pm 0.3$ & $6.3 \pm 0.3$ & 49.1 & 10.6 & 4.6 \\
\hline & 1980 & $-20.5 \pm 0.2$ & $5.9 \pm 0.2$ & 48.3 & 10.7 & 4.5 \\
\hline & 1979 & $-21.6 \pm 0.1$ & $5.7 \pm 0.4$ & 43.3 & 10.0 & 4.3 \\
\hline & 1978 & $-21.4 \pm 0.2$ & $6.2 \pm 0.2$ & 48.6 & 10.6 & 4.6 \\
\hline & 1977 & $-21.0 \pm 0.1$ & $6.1 \pm 0.3$ & 47.1 & 10.6 & 4.4 \\
\hline & 1976 & $-23.2 \pm 0.1$ & $7.7 \pm 0.1$ & 47.7 & 11.1 & 4.3 \\
\hline & 1975 & $-21.1 \pm 0.0$ & $5.2 \pm 0.2$ & 49.9 & 10.5 & 4.7 \\
\hline & 1974 & $-21.5 \pm 0.2$ & $6.1 \pm 0.1$ & 47.8 & 11.4 & 4.2 \\
\hline & 1973 & $-22.0 \pm 0.1$ & $6.5 \pm 0.1$ & 48.2 & 11.2 & 4.3 \\
\hline & 1972 & $-23.5 \pm 0.0$ & $5.1 \pm 0.2$ & 48.9 & 11.5 & 4.2 \\
\hline & 1971 & $-22.5 \pm 0.1$ & $5.7 \pm 0.3$ & 48.9 & 10.7 & 4.6 \\
\hline & 1970 & $-22.5 \pm 0.2$ & $5.2 \pm 0.1$ & 49.6 & 11.5 & 4.3 \\
\hline & 1969 & $-22.3 \pm 0.2$ & $5.0 \pm 0.2$ & 47.9 & 11.8 & 4.1 \\
\hline & 1968 & $-23.5 \pm 0.3$ & $7.3 \pm 0.1$ & 50.9 & 9.4 & 5.4 \\
\hline
\end{tabular}

${ }^{a}$ This study, all guano collected under Tadarida brasiliensis.

b Mizutani et al., 1992b, where guano was collected under T. brasiliensis unless noted by Msp, Mc or Mv where guano was collected under Macrotus sp., Macrotus californicus, or Myotus velifer, respectively.

c Des Marais et al., 1980.

d Date of collection for all samples, but those from Eagle Creek, where annually banded guano enabled assignment of a year to each collected sample.

e \pm Indicates standard deviations on repeat measurements of the same sample. A blank value indicates unknown value.

into centrifuge tubes and dated by counting the annual dark-light couplets from the surface. We are reasonably confident of our chronology as Altenbach and Petit (1972) had previously shown that annual stratigraphy was easily visible from 1954 to 1971. Moreover, McFarlane and Keeler (1990) had previously used guano deposition from this site as a proxy for Mexican free-tailed bat population at this cave. 


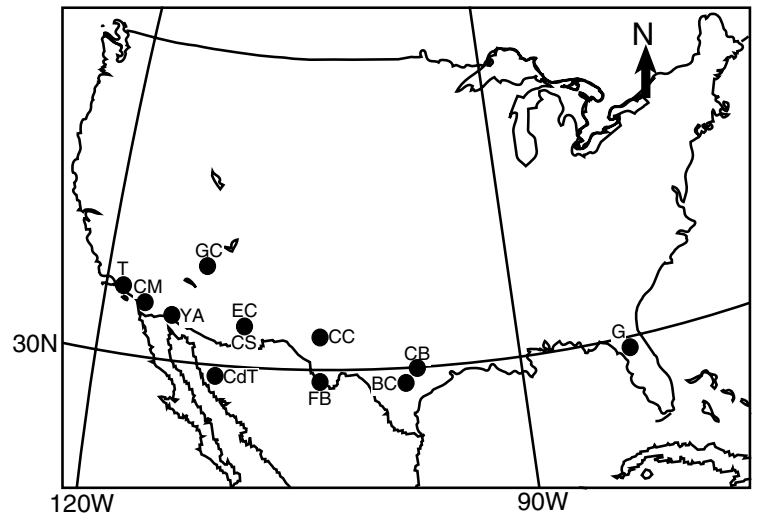

Fig. 1. Map of guano collection sites. Study sites correspond to Table 1, where $\mathrm{T}$ is Topanga (CA); CM is California mine (CA); YA is Yuma mine adit (CA); GC is Bat Cave, Grand Canyon (AZ); CdT is Cueva del Tigre, Sonora, Mexico; EC and CS are Eagle Creek Cave, and Coonsprings Cave (AZ) (100 km apart); CC is Carlsbad Caverns (NM); FB is Fresno Creek Bridge (TX); BC is Bracken Cave (TX); $\mathrm{CB}$ is Congress Bridge (TX); and $\mathrm{G}$ is Gainesville (FL).

\subsection{Experimental procedures}

Modern guano from $T$. brasiliensis is produced in pellets, visually determined to mostly be composed of insect cuticles and bat hair. Each sample was placed in $2 \mathrm{~N} \mathrm{HCl}$ for $3 \mathrm{~h}$ to remove carbonate, and then neutralized by passing de-ionized water through the sample placed on a $60-\mu \mathrm{m}$ sieve. Each sample was then lypholized, followed by crushing and homogenization using a planetary micromill for $3 \mathrm{~min}$. During the summer of $2006, \delta^{13} \mathrm{C}$ and $\delta^{15} \mathrm{~N}$ values, carbon and nitrogen weight percent $(\% \mathrm{C}$ and $\% \mathrm{~N}$, respectively), and $\mathrm{C}: \mathrm{N}$ ratios were determined using a Costech Elemental Analyzer fitted with a zero-blank auto-sampler coupled via a ConFloII to a ThermoFinnigan DeltaPlusXL using Continuous-Flow Isotope Ratio Mass Spectrometry (CF-IRMS) at the University of St Andrews Facility for Earth and Environmental Analysis stable isotope laboratory. At least two measurements were analyzed for each sample and the average is reported along with the SD in Table 1. Stable isotope results are reported as per mil (\%o) deviations from the VPDB and AIR reference standard scale for $\delta^{13} \mathrm{C}$ and $\delta^{15} \mathrm{~N}$ values, respectively. Precisions (SD) on internal standards were better than $\pm 0.2 \%$ and $0.3 \%$ for carbon and nitrogen, respectively.

\subsection{Meteorological data, climate indexes, and vegetation estimates}

We obtained monthly mean temperature and monthly precipitation totals for nearest available sites from NOAA (Williams et al., 2005). Stable isotope data for spatially distributed modern samples were regressed against Mean Annual Temperature (MAT), Mean Annual Precipitation (MAP), seasonal precipitation totals (summer and winter), and precipitation ratio for summer and winter. Five-year means over the period prior to guano collection were determined for each of these meteorological variables. We estimated the relative abundance of $\mathrm{C}_{4}$ grass using spatial relationships (latitude and longitude) from Paruelo and Lauenroth (1996) for sites within the western United States that were covered in their analysis. For comparison with the time-series $\delta^{13} \mathrm{C}$ and $\delta^{15} \mathrm{~N}$ values from Eagle Creek Cave, southeast Arizona, we also obtained monthly estimates for Palmer Drought Severity Index (PDSI) from NOAA for Region 7, Arizona (http://www.ncdc.noaa. gov/oa/climate/onlineprod/drought/xmgr.html), and $\mathrm{Li}$ and Zeng $(2002$, 2005) North American Monsoon Index annual values from 1968 to 1988.

\section{RESULTS}

\subsection{Modern guano $\delta^{13} \mathrm{C}$ and $\delta^{15} \mathrm{~N}$ values}

Excluding guano collected at Cueva del Tigre, Sonora, Mexico, $\% \mathrm{C}, \% \mathrm{~N}$, and $\mathrm{C}: \mathrm{N}$ ratios were consistent among samples. Weight percent of organic carbon ranged 51 to $44 \%$; $\% \mathrm{~N}$ ranged from 9 to 11 , and $\mathrm{C}: \mathrm{N}$ ratio ranged from 4.4 to 5 . However, guano at Cueva del Tigre had lower $\% \mathrm{C}$ and $\% \mathrm{~N}$, and a higher $\mathrm{C}: \mathrm{N}$ ratio. Individual guano pellets were collected from just outside the cave as the bats were flying out for their evening feed. It is possible that the high $\mathrm{C}: \mathrm{N}$ ratio is due to a notable lack of hair in the guano relative to other samples. (Table 1). Across the transect, $\delta^{13} \mathrm{C}$ values ranged from $-17.8 \%$ to $-27.4 \%$ VPDB, and $\delta^{15} \mathrm{~N}$ values ranged $3.7 \%$ o to $7.9 \%$ oAIR (Table 1). Both $\delta^{13} \mathrm{C}$ and $\delta^{15} \mathrm{~N}$ values displayed trends consistent with geographic location (Fig. 2). In particular, $\delta^{13} \mathrm{C}$ values have highest values in Texas that decreased both westward and eastward. $\delta^{15} \mathrm{~N}$ values in Arizona, Sonora, and Texas (the NAMS region) are inversely and linearly correlated with

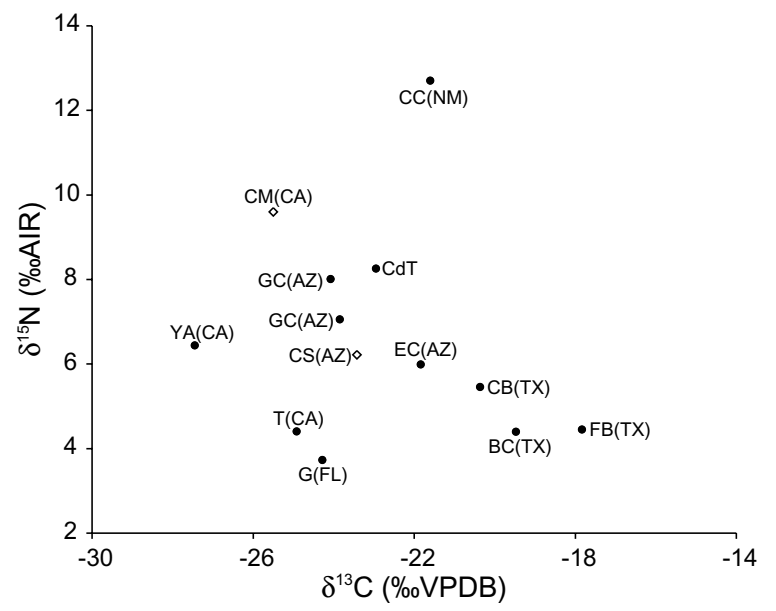

Fig. 2. Plot of $\delta^{13} \mathrm{C}$ and $\delta^{15} \mathrm{~N}$ values of guano collected from the southern United States and northwest Mexico. Eagle Creek is the average of yearly measurements from 1968 to 1987. Study sites correspond to Table 1 and Fig. 1, where $\mathrm{T}$ is Topanga (CA); CM is California mine (CA); YA is Yuma mine adit (CA); GC is Bat Cave, Grand Canyon, (AZ); CdT is Cueva del Tigre, Sonora, Mexico; EC and CS are Eagle Creek Cave, and Coonsprings Cave (AZ); CC is Carlsbad Caverns (NM); FB is Fresno Creek Bridge (TX); BC is Bracken Cave (TX); CB is Congress Bridge (TX); and $\mathrm{G}$ is Gainesville (FL). 
$\delta^{13} \mathrm{C}$ values (excluding a previously published value that had a more positive $\delta^{15} \mathrm{~N}$ value). When we compared guano $\delta^{13} \mathrm{C}$ values to estimated relative abundances of $\mathrm{C}_{4}$ grass, we found a highly significant linear relationship, which became stronger when $\delta^{13} \mathrm{C}$ values of guano from other insectivorous bat species were included in the analysis (Table 2 and Fig. 3). $\delta^{13} \mathrm{C}$ values varied predictably according to general climate patterns among western sites, with strongest correlations to summer precipitation amount and winter precipitation ratio (Table 2). The lowest $\delta^{13} \mathrm{C}$ value was found for the sample from Yuma, which had very low total precipitation, and hence was likely to be dominated by $\mathrm{C}_{3}$ vegetation. Eliminating Yuma from the regression yielded a significant relationship between $\delta^{13} \mathrm{C}$ value and MAT. We did not find significant relationships among meteorological variables and $\delta^{15} \mathrm{~N}$ values.

\subsection{Temporal expression of guano $\delta^{13} \mathrm{C}$ and $\delta^{15} \mathrm{~N}$ values}

Guano samples at Eagle Creek Cave were obtained from 1968 to 1987 . No temporal pattern was found for $\% \mathrm{C}, \% \mathrm{~N}$, nor $\mathrm{C}: \mathrm{N}$ ratios, which remained generally consistent and similar to the recent samples implying limited diagenesis over the 20 years of burial (Table 1$). \delta^{13} \mathrm{C}$ and $\delta^{15} \mathrm{~N}$ values of guano at Eagle Creek did not covary. $\delta^{13} \mathrm{C}$ values ranged from $-19.7 \%$ to $-23.6 \%$ VPDB, nearly half of the total range found for the spatial samples, while $\delta^{15} \mathrm{~N}$ values ranged $2.7 \%$. No consistent trend was observed with time, although $\delta^{13} \mathrm{C}$ values generally increased from 1968 to 1987. Although, relatively more negative $\delta^{13} \mathrm{C}$ values

Table 2

Correlations between variables and stable isotope values of bat guano across the southwest United States

\begin{tabular}{lccr}
\hline Covariates & $\mathrm{df}^{\mathrm{a}}$ & $F$ value $^{\mathrm{b}}$ & \multicolumn{1}{r}{} \\
\hline$\delta^{13}$ C against & & & \\
$\mathrm{C}_{4} \%$ (T. brasiliensis) & 1,7 & $14.87^{* *}$ & 0.77 \\
$\mathrm{C}_{4} \%$ (all) & 1,10 & $27.19^{* * *}$ & 0.86 \\
MAP & 1,9 & 0.96 & 0.31 \\
JJA precipitation & 1,9 & $22.38^{* *}$ & 0.84 \\
DJF precipitation & 1,9 & 1.31 & -0.37 \\
JJA/MAP & 1,9 & 6.29 & 0.64 \\
DJF/MAP & 1,9 & $12.21^{* *}$ & -0.76 \\
MAT & 1,9 & 1.0 & 0.31 \\
$\delta^{15} N$ against & & & \\
MAP & 1,5 & 1.64 & -0.50 \\
JJA precipitation & 1,5 & 0.57 & -0.32 \\
DJF precipitation & 1,5 & 1.22 & -0.45 \\
JJA/MAP & 1,5 & 0.08 & 0.14 \\
DJF/MAP & 1,5 & 0.03 & -0.10 \\
MAT & 1,5 & 1.74 & 0.51 \\
$\delta^{13} C$ excluding Yuma against & & \\
MAP & 1,8 & 0.05 & 0.08 \\
JJA precipitation & 1,8 & $18.79^{* *}$ & 0.84 \\
DJF precipitation & 1,8 & 6.46 & -0.67 \\
JJA/MAP & 1,8 & $11.34^{* *}$ & 0.77 \\
DJF/MAP & 1,8 & $19.00^{* *}$ & -0.84 \\
MAT & 1,8 & $9.44^{*}$ & 0.74 \\
\hline D Degres of fred & &
\end{tabular}

${ }^{\mathrm{a}}$ Degrees of freedom (numerator, denominator).

b ${ }^{*} p<0.025,{ }^{* *} p<0.01,{ }^{* * *} p<0.001$.

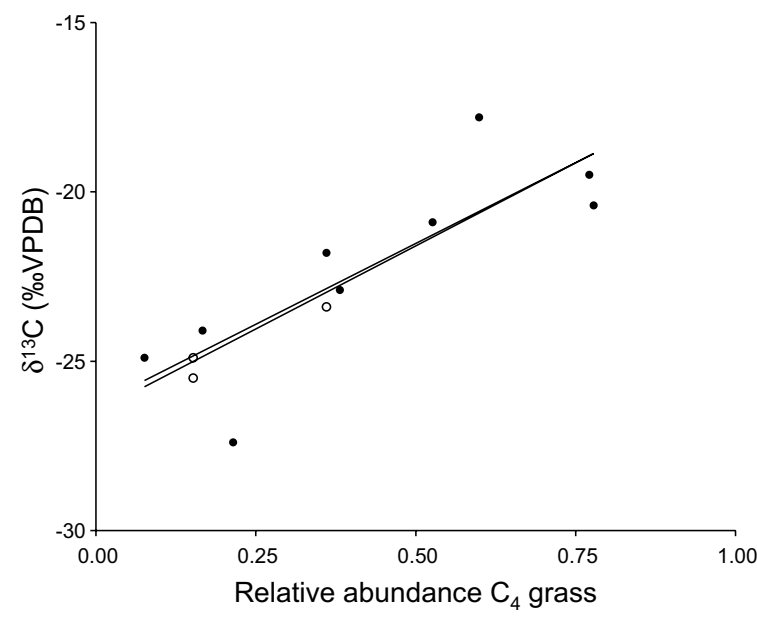

Fig. 3. Measured $\delta^{13} \mathrm{C}$ values of insectivorous bat guano as a function of inferred relative abundance of $\mathrm{C}_{4}$ grass. Relative abundance of $\mathrm{C}_{4}$ grass was determined using a regression from Paruelo and Lauenroth (1996) where relative abundance of $\mathrm{C}_{4}$ grass $=15.9339-3.2460 \cdot \ln ($ longitude $)-0.0003072 \cdot(\text { latitude })^{2}$, where latitude and longitude are in degrees. Filled circles indicate Tadarida brasiliensis guano, open circles indicates guano from other insectivorous bat species. Linear regression equation through all data is $\delta^{13} \mathrm{C}=9.8$ (relative abundance $\mathrm{C}_{4}$ grass) -26.5 $\left(r^{2}=0.73, n=12, p<0.001\right)$; linear regression through $T$. brasiliensis guano only is $\delta^{13} \mathrm{C}=9.5$ (relative abundance $\mathrm{C}_{4}$ grass) -26.3 $\left(r^{2}=0.68, n=9 ; p<0.01\right)$.

occurred during 1968, 1972, 1976, and 1980-1983 that may have corresponded with an ENSO event (Redmond and Koch, 1991), La Niña events are not indicated by relatively more positive $\delta^{13} \mathrm{C}$ values; and there is no significant relationship with the Southern Oscillation Index (SOI) (Fig. 4). Guano $\delta^{13} \mathrm{C}$ values correlated significantly with PDSI with a 1-year lag (Fig. 5), and with NAMSI, filtered using a three-year running mean (Table 3 ). Correlations between PDSI and $\delta^{13} \mathrm{C}$ values were strongest during winter months, and improved further when years with distinct negative excursions were excluded. Despite these relationships, we found only significant correlations between $\delta^{13} \mathrm{C}$ and summer precipitation ratio and spring average temperature when data sets were compared using three-year running means (Table 3). We did not find significant relationships between $\delta^{15} \mathrm{~N}$ and any index nor meteorological variable.

\section{DISCUSSION}

\section{1. $\delta^{13} \mathrm{C}$ values of bat guano records local environment}

Bat guano $\delta^{13} \mathrm{C}$ values from several insectivorous bats appear to faithfully record information relating to environment and climate through non-specific habitat use. Relative abundance of $\mathrm{C}_{4}$ grasses, and relative abundance of $\mathrm{C}_{3}$ grasses and shrubs were estimated using equations in Paruelo and Lauenroth (1996) who found geographical patterns in the relative abundance of $\mathrm{C}_{4}$ grasses, $\mathrm{C}_{3}$ grasses, and shrubs for the western United States. In accordance with the Quantum Yield Theory and expected photosynthetic 


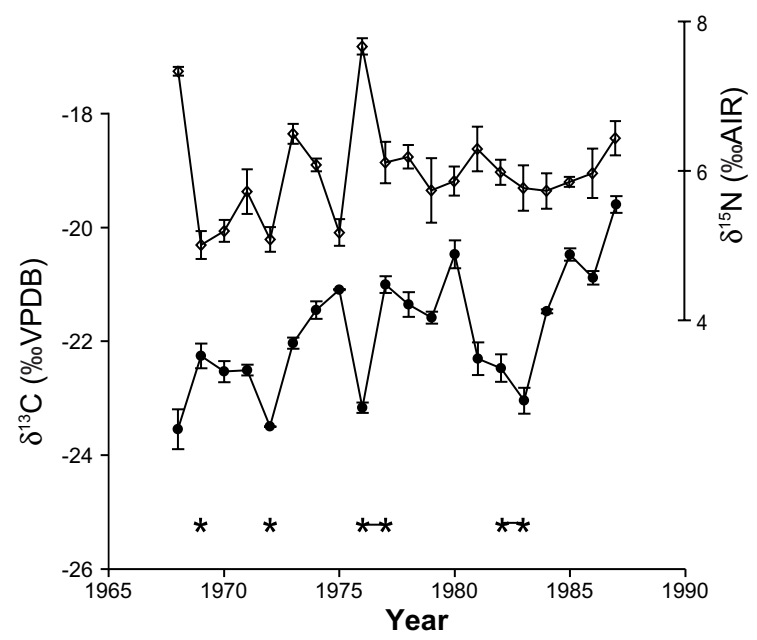

Fig. 4. $\delta^{13} \mathrm{C}$ and $\delta^{15} \mathrm{~N}$ values of Tadarida brasiliensis bat guano collected from Eagle Creek Cave, Arizona. The annually laminated guano deposit from this cave permitted assignment of specific years to each sample. Also indicated are strong ENSO events over the same time frame (stars).

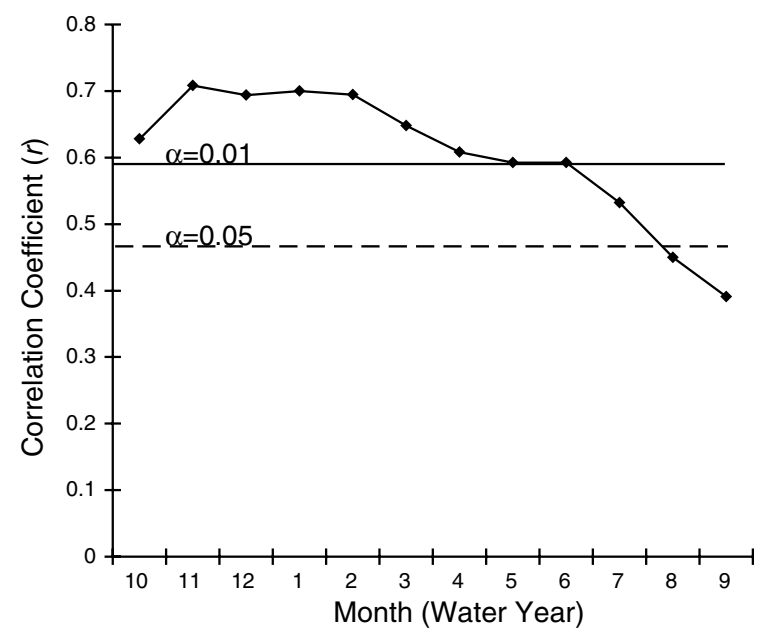

Fig. 5. Correlation coefficients for monthly PDSI (1-year lead, water year) regressed against annual $\delta^{13} \mathrm{C}$ values of Tadarida brasiliensis guano at Eagle Creek Cave (AZ), for the time 19681987. Winter and spring PDSI values prior to the growing season show strong and significant correlations with $\delta^{13} \mathrm{C}$ guano values of the following year.

efficiencies (Ehleringer, 1978; Ehleringer et al., 1997), $\mathrm{C}_{3}$ grasses replace $\mathrm{C}_{4}$ grasses at higher latitude and correspondingly cooler temperatures (Epstein et al., 1997; Tieszen et al., 1997). However, $C_{3}$ shrubs replace $C_{4}$ grasses as climates become more arid toward the west within our study area favouring plants with deep roots that can tap into groundwater resources (Paruelo and Lauenroth, 1996). We found strong and significant relationships between $\delta^{13} \mathrm{C}$ values of guano and calculated relative abundance of $\mathrm{C}_{4}$ grass.

We measured the most negative $\delta^{13} \mathrm{C}$ value for a sample taken at Yuma, which is also the site with the lowest MAP and highest relative winter precipitation confirming the observation that $\mathrm{C}_{3}$ shrubs should dominate the lowest rainfall regions, with relatively few $\mathrm{C}_{4}$ grasses. Another possibility is increased intake of $\mathrm{C}_{3}$ crops. Additionally, we measured the most positive $\delta^{13} \mathrm{C}$ values for a sample collected at Fresno Creek (TX), the location with the greatest proportion of summer precipitation indicating that there may have been a larger proportion of $\mathrm{C}_{4}$ grasses present than estimated using spatial relationships alone. Moreover, this part of western Texas is known contain high abundances of succulents that will also serve to increase $\delta^{13} \mathrm{C}$ values (Aide and Van Auken, 1985). Therefore, both the Yuma and Fresno Creek (TX) sites likely contain vegetation not expected from spatial patterns alone. Nonetheless, Paruelo and Lauenroth's (1996) model predicts vegetation with an $r^{2}=0.61$, and our comparison indicates bat guano $\delta^{13} \mathrm{C}$ values track expected natural vegetation patterns despite potential modifying influences. We did not include the site in Florida in the analysis as it lay outside Paruelo and Lauenroth's (1996) regional analysis, but our measured value of $-24.3 \%$ would be expected in a largely arboreal $\mathrm{C}_{3}$ vegetation mix, with some subtropical $\mathrm{C}_{4}$ grasses present (Choi et al., 2001; Huang et al., 2006). Our results for non-specific habitat use for insectivorous bats also agree with non-specific habitat use for the big brown bat (Eptesicus fuscus) in northern United States (Sullivan et al., 2006).

$\delta^{13} \mathrm{C}$ values of bat guano can only predict climate to the extent that $\mathrm{C}_{4} / \mathrm{C}_{3}$ plant ratios are influenced by climate, and so we find similar predictive power of bat guano $\delta^{13} \mathrm{C}$ values to discriminate meteorological variables as has been described for vegetation (Paruelo and Lauenroth, 1996; Weiss et al., 2004). Moreover, CAM plants in the NAMS region tend to have $\delta^{13} \mathrm{C}$ values similar to or more positive than cohabiting $\mathrm{C}_{4}$ grasses (-12\%o) (Des Marais et al., 1980; Flemming et al., 1993). Any incorporation of insects that host these plants (e.g., the Yucca moth) to the bat's diet will shift faecal dietary values higher and obscure a direct estimation of $\mathrm{C}_{4}$ vegetation.

The most significant comparisons among meteorological variables and guano $\delta^{13} \mathrm{C}$ values over the western United States were total summer precipitation amount, and winter precipitation ratio. Summer precipitation amount decreased westward as the importance of monsoonal moisture gave way to winter precipitation dominance. It is not surprising that precipitation was found to be a better predictor than MAT, as the sampling points tended to cluster along a similar latitudinal band, and MAT among sampling locations did not vary greatly. By contrast, large changes in both the amount and timing of precipitation occurred along our sampling transect. However, there is also a significant relationship between MAT and $\delta^{13} \mathrm{C}$ values of bat guano if the sample at Yuma is eliminated. Therefore, we also find MAT as a contributor of the relative abundance of $\mathrm{C}_{4}$ grass given enough precipitation for growth, consistent with other studies (Ehleringer, 1978; Paruelo and Lauenroth, 1996; Ehleringer et al., 1997). Clearly, the Yuma sample is from a site where precipitation is limiting.

At Eagle Creek cave, we were able to examine annual variability in $\delta^{13} \mathrm{C}$ values. The most significant correlations are found between PDSI (with a 1-year lead for a given 
Table 3

Time-series correlations between meteorological variables/climate indexes and stable isotope values of bat guano at Eagle Creek Cave

\begin{tabular}{|c|c|c|c|c|c|}
\hline \multirow[t]{3}{*}{ Covariate 1} & \multicolumn{5}{|c|}{ Covariate 2} \\
\hline & \multicolumn{2}{|l|}{$\delta^{13} \mathrm{C}$} & \multicolumn{3}{|l|}{$\delta^{15} \mathrm{~N}$} \\
\hline & $F$ value $^{\mathrm{a}}$ & $r$ & $F$ value $^{\mathrm{a}}$ & $r$ & $\mathrm{df}^{\mathrm{b}}$ \\
\hline Total precipitation (water year) & 0.157 & 0.09 & 0.052 & -0.05 & 1,18 \\
\hline JJA total precipitation & 0.491 & -0.16 & 0.002 & 0.01 & 1,18 \\
\hline DJF total precipitation & 0.075 & 0.06 & 0.354 & 0.16 & 1,18 \\
\hline JJA/annual precipitation & 0.997 & -0.23 & 1.650 & 0.29 & 1,18 \\
\hline DJF/annual precipitation & 0.107 & 0.08 & 1.259 & 0.26 & 1,18 \\
\hline MAT & 0.932 & 0.04 & 0.178 & -0.10 & 1,18 \\
\hline Mean summer temperature (JJAS) & 0.000 & 0.00 & 2.696 & -0.36 & 1,18 \\
\hline Mean spring temperature (AM) & 2.050 & 0.10 & 0.020 & 0.04 & 1,18 \\
\hline Mean winter temperature (DJF) & 0.012 & 0.00 & 0.746 & 0.40 & 1,18 \\
\hline NAMSI & $7.240^{*}$ & -0.54 & & & 1,18 \\
\hline \multicolumn{6}{|l|}{ Three-point running means } \\
\hline Summer precipitation ratio & $8.670^{* *}$ & & & & 1,16 \\
\hline Spring temperature (AM) & $7.835^{*}$ & & & & 1,16 \\
\hline NAMSI & $15.070^{* *}$ & -0.70 & & & 1,16 \\
\hline PDSI (1-year lead) & $8.420^{*}$ & 0.82 & & & 1,16 \\
\hline
\end{tabular}

a ${ }^{*} p<0.025,{ }^{* *} p<0.01$.

b Degrees of freedom (numerator, denominator).

water year) and $\delta^{13} \mathrm{C}$ values, and between NAMSI and $\delta^{13} \mathrm{C}$ values, particularly if a running mean is used to integrate years (Table 3). Although, we found that ENSO events may be associated with distinct negative excursions of bat guano $\delta^{13} \mathrm{C}$ values, we failed to find a correlation between $\mathrm{SOI}$ and $\delta^{13} \mathrm{C}$ values. There is a teleconnection between El Niño events and increased winter precipitation in the southwest US (Leavitt et al., 2002) contributing to increased $\mathrm{C}_{3}$ vegetation, and other studies have found increased $\mathrm{C}_{3}$ grass abundance during El Niño years with corresponding decreases in ecosystem $\delta^{13} \mathrm{C}$ values (Stapp et al., 1999; Smith et al., 2002). However, we fail to find a corresponding increase in $\delta^{13} \mathrm{C}$ values during La Niña years, which are thought to be associated with dryer winters (Leavitt et al., 2002). Moreover, we did not note a direct response of high precipitation amount during ENSO events near Eagle Creek Cave. This obscures a necessary mechanism that would lead to more negative $\delta^{13} \mathrm{C}$ values of guano during ENSO years. Indeed, we found only summer precipitation ratio and spring temperatures to be related to $\delta^{13} \mathrm{C}$ guano variability. The correlation is further improved if the more negative $\delta^{13} \mathrm{C}$ values associated with ENSO events are removed. Interestingly, drought conditions are related to more negative $\delta^{13} \mathrm{C}$ values. This may have occurred by both favouring $\mathrm{C}_{3}$ shrubs that can tap into groundwater resources, and by eliminating annual $\mathrm{C}_{4}$ grasses that require a certain critical amount of precipitation to grow (e.g., Paruelo and Lauenroth, 1996; Collatz et al., 1998). By contrast, $\mathrm{C}_{3}$ grasses may be favoured by increased precipitation, particularly if that precipitation occurred in the winter/spring. If plant functional types can be discriminated, the power to predict meteorological variability might increase. For example, $\delta^{13} \mathrm{C}$ values of $\mathrm{C}_{3}$ shrubs and grasses cannot be discerned using guano $\delta^{13} \mathrm{C}$ value alone, yet shrubs are more influenced by precipitation and less by temperature variation than $\mathrm{C}_{3}$ grasses (Paruelo and Lauenroth, 1996).
Likewise CAM vegetation cannot be discerned from $\mathrm{C}_{4}$ grasses via $\delta^{13} \mathrm{C}$ alone. The addition of other geochemical markers of guano (for example, $\delta \mathrm{D}$ and $\delta^{18} \mathrm{O}$ values, or elemental ratios/lipid biomarkers) may help better resolve plant functional types and climate.

We infer that bats sample insects feeding on the vegetation over a large spatial area that integrates an environmental signal related to large-scale atmospheric variability. The vegetation is an integrator of longer-term climatic changes rather than year-to-year variability of one principal variable. These results indicate that no simple relationship exists between components of the climate-vegetation-insect-bat system. Several complications may arise from each component along this chain. We have already discussed that vegetation is not solely responding to one meteorological variable, and $\delta^{13} \mathrm{C}$ cannot resolve some plant functional types. Although it is reasonable to expect insect abundance to match plant abundance, insect chitin can be produced at varying life stages and seasons. Migratory insects can bring vegetative information about other geographic locations (Wassenaar and Hobson, 1998; Lee and McCracken, 2005), sometimes in large numbers, and agricultural areas will bring insects containing vegetation information not directly related to the local climate (Lee and McCracken, 2005). Bats are known to capture insects over agricultural areas and at high altitudes, and bulk guano contains not only insect chitin, but bat hair that may not have formed contemporaneously with other components in the guano (Cryan et al., 2004). Moreover, bats are seasonal residents in Arizona and Texas, and year-round residents in California (Cockrum, 1969) and therefore collected guano will be influenced by the degree of seasonality in the vegetation $\delta^{13} \mathrm{C}$ values. A next step might be to isolate components within the guano to determine if more reliable proxy-information can be obtained. 


\section{2. $\delta^{15} \mathrm{~N}$ values as a record of the environment}

Tadarida brasiliensis bat guano $\delta^{15} \mathrm{~N}$ and $\delta^{13} \mathrm{C}$ values collected for this study did not co-vary when all sites were considered, but tended to co-vary within sites influenced by the NAMS. In Texas, New Mexico and Arizona, and Sonora we found a linear relationship between $\delta^{13} \mathrm{C}$ and $\delta^{15} \mathrm{~N}$, however, inclusion of other published data obscured this result. At Eagle Creek Cave, $\delta^{15} \mathrm{~N}$ values are apparently not strongly related to those meteorological variables that we examined. $\delta^{15} \mathrm{~N}$ values of chitin have been linked with trophic level (Schimmelmann et al., 1998); however, a feeding trial determined chitin nitrogen to contain recycled ammonia and not to be influenced by a change in dietary $\delta^{15} \mathrm{~N}$ values (Webb et al., 1998). Both these studies concluded ${ }^{15} \mathrm{~N}$ in chitin was depleted relative to source material, whereas we find values that are more positive. Organic matter $\delta^{15} \mathrm{~N}$ values in arid regions are often correlated with precipitation (e.g., Sealy et al., 1987), and $\delta^{15} \mathrm{~N}$ value of faecal material is known to be similar to diet and body tissues (e.g., Sponheimer et al., 2003). We found a large difference in $\delta^{15} \mathrm{~N}$ values amongst our modern spatial samples, but relatively little within our time-series, suggesting $\delta^{15} \mathrm{~N}$ to be more dependent on local soils. Despite some indication of $\delta^{13} \mathrm{C}$ and $\delta^{15} \mathrm{~N}$ covariation within the NAMS region, we do not find $\delta^{15} \mathrm{~N}$ to be a faithful archive of climate.

\section{CONCLUSIONS}

Despite potential complications, we found bulk $\delta^{13} \mathrm{C}$ values of bat guano to faithfully record local vegetation and climate signals across large geographic scales along a varying climatic gradient. Moreover, large-scale atmospheric and climatic variability such as NAMS, and drought appears better resolved than local year-to-year meteorological variability. Therefore, there is considerable potential for $\delta^{13} \mathrm{C}$ from long-term guano deposits to discern climate variability in areas where abrupt climate changes are difficult to otherwise determine. Guano deposits from insectivorous bats may yield information related to the local abundance of dominant plant functional types, giving considerable power to discern ecosystem level carbon storage and flow in regions where sediments are not easily captured.

There are large deposits of guano to be excavated throughout the world, most notably in the semi-arid sub-tropics, and humid tropics, where time-series palaeoenvironmental records are difficult to obtain. Many meters of guano deposits can be recovered from many known deposits in Asia, Africa, and the Americas; and have long been a source of fertilizer for local agriculture. Guano deposits are just now beginning to be utilized as a palynological resource of palaeoenvironmental information (e.g., Maher, 2006). We showed that bulk $\delta^{13} \mathrm{C}$ and $\delta^{15} \mathrm{~N}$ values of modern and short-term guano deposits contain a valuable record of vegetation and climate, and indicate its potential for recovering both long-term and highresolution records.

\section{ACKNOWLEDGMENTS}

This research was funded by NERC Large Grant NE/D001501/ 1. We thank Ray Keeler and members of the Central Arizona Grotto of the National Speleological Society, and Phillip Thompson for help in collecting the material. We also thank anonymous reviewers for their insightful comments.

\section{REFERENCES}

Adams D. K., and Comrie A. C. (1997) The North American Monsoon. Bull. Am. Meteorol. Soc. 78, 2197-2212.

Aide M., and Van Auken W. (1985) Chihuahuan desert vegetation of limestone and basalt slopes in west Texas. Southwestern Natural. 30, 533-542.

Altenbach J. S., and Petit M. G. (1972) Stratification of guano deposits of the free-tailed bat Tadarida brasiliensis. J. Mammal. 53, 890-893.

Choi Y., Wang Y., Hsieh Y. P., and Robinson L. (2001) Vegetation succession and carbon sequestration in a coastal wetland in northwest Florida: evidence from carbon isotopes. Glob. Biogeochem. Cycles 15, 311-319.

Cockrum E. L. (1969). Migration in the Guano bat, Tadarida brasiliensis. Univ. Kans. Mus. Nat. Hist. Misc. Publ. 51, 303336.

Collatz G. J., Berry J. A., and Clark J. S. (1998) Effects of climate and atmospheric $\mathrm{CO}_{2}$ partial pressure on the global distribution of $\mathrm{C}_{4}$ grasses: present, past, and future. Oecologia 114, 441-454.

Cryan P. M., Bogan M. A., Rye R. O., Landis G. P., and Kester C. L. (2004) Stable hydrogen isotope analysis of bat hair as evidence for seasonal molt and long-distance migration. $J$. Mammal. 85, 995-1001.

deMenocal P. B., Oritz J., Guilderson T., Adkins J., Sarnthein M., Baker L., and Yarusinki M. (2000) Abrupt onset and termination of the African Humid Period: rapid climate response to gradual insolation forcing. Quatern. Sci. Rev. 19, 347-361.

Des Marais D. J., Mitchell J. M., Meinschein W. G., and Hayes J. M. (1980) The carbon isotope biogeochemistry of the individual hydrocarbons in bat guano and the ecology of the insectivorous bats in the region of Carlsbad, New Mexico. Geochim. Cosmochim. Acta 44, 2075-2086.

Ehleringer J. R. (1978) Implications of quantum yield differences on the distributions of $\mathrm{C}_{3}$ and $\mathrm{C}_{4}$ grasses. Oecologia 31, 255-267.

Ehleringer J. R., Cerling T. E., and Helliker B. R. (1997) $\mathrm{C}_{4}$ photosynthesis, atmospheric $\mathrm{CO}_{2}$, and climate. Oecologia 112, 285-299.

Epstein H. E., Lauenroth W. K., Burke I. C., and Coffin D. P. (1997) Productivity patterns of $\mathrm{C}_{3}$ and $\mathrm{C}_{4}$ functional types in the U.S. Great Plains. Ecology 78, 722-731.

Flemming T. H., Nuñez R. A., and Sternberg L. S. L. (1993) Seasonal changes in the diets of migrant and non-migrant nectarivorous bats as revealed by carbon stable isotope analysis. Oecologia 94, 72-75.

Huang Y., Shuman B., Wang Y., Webb, III, T., Grimm E. C., and Jacobson, Jr., G. L. (2006) Climatic and environmental controls on the variation of $\mathrm{C}_{3}$ and $\mathrm{C}_{4}$ plant abundances in central Florida for the past 62,000 years. Palaeogeogr. Palaeoclimatol. Palaeoecol. 237, 428-435.

Leavitt S. W., Wright W. E., and Long A. (2002) Spatial expression of ENSO, drought, and summer monsoon in seasonal $\delta^{13} \mathrm{C}$ of ponderosa pine tree rings in southern Arizona and New Mexico. J. Geophys. Res. 107(D18), 4349. doi:10.1029/ 2001JD001312. 
Lee Y. F., and McCracken G. F. (2005) Dietary variation of Brazilian free-tailed bats links to migratory populations of pest insects. J. Mammal. 86, 67-76.

Li J., and Zeng Q. (2002) A unified monsoon index. Geophys. Res. Lett. 29, 1274. doi:10.1029/2001GL013874.

Li J., and Zeng Q. (2005) A new monsoon index, its interannual variability and relation with monsoon precipitation. Clim. Environ. Res. 10, 351-365.

Lin G. H., Phillips S. L., and Ehleringer J. R. (1996) Monsoonal precipitation responses of shrubs in a cold desert community on the Colorado Plateau. Oecologia 06, 8-17.

Maher, Jr., L. J. (2006) Environmental information from guano palynology of insectivorous bats of the central part of the United States of America. Palaeogeogr. Palaeoclimatol. Palaeoecol. 237, 19-31.

McFarlane D. A., and Keeler R. C. (1990). A proxy population record for the Mexican free-tailed bat at Eagle Creek cave, Arizona. In Proceedings, Symposium on Managing Wildlife in the Southwest, pp. 100-106. Wildlife Society, Tuscon, Arizona.

Mizutani H., McFarlane D. A., and Kabaya Y. (1992a) Nitrogen and carbon isotope study of a bat guano core from Eagle Creek Cave, Arizona, USA. Mass Spectrosc. 40, 57-65.

Mizutani H., McFarlane D. A., and Kabaya Y. (1992b) Carbon and nitrogen isotopic signatures of bat guanos as a record of past environments. Mass Spectrosc. 40, 67-82.

Palmer W. C. (1965) Meteorological Drought, Weather Bur. Res. Pap. 45, US Department of Agriculture, U.S. Gov. Print. Off., Washington, D.C.

Paruelo J. M., and Lauenroth W. K. (1996) Relative abundance of plant functional types in grasslands and shrublands of North America. Ecol. Appl. 6, 1212-1224.

Quinn W. H., Neal V. T., and Antunez de Mayolo S. E. (1987) El Niño occurrences over the past four and a half centuries. $J$. Geophys. Res. 92, 14449-14461.

Redmond K. T., and Koch R. W. (1991) Surface climate and streamflow variability in the Western United-States and their relationship to large-scale circulation indexes. Water Resour. Res. 27, 2381-2399.

Schimmelmann A., Wintsch R. P., Lewan M. D., and DeNiro M. J. (1998) Chitin: 'Forgotten' Source of Nitrogen - from modern chitin to thermally mature kerogen: lessons from nitrogen isotope ratios. In Nitrogen-containing Macromolecules in the Biosphere-Geosphere (eds. B. A. Stankiewicz and P. F. Bergen), ACS Symp. Ser. 707, pp. 226-242.

Schwinning S., Davis K., Richardson L., and Ehleringer J. R. (2002) Dueterium enriched irrigation indicates different forms of rain use in shrub/grass species of the Colorado Plateau. Oeocologia 130, 345-355.

Schwinning S., Starr B. I., and Ehleringer J. R. (2003) Dominant cold desert plants do not partition warm season precipitation by event size. Oecologia 136, 252-260.

Sealy J. C., van der Merwe N. J., Lee Thorp J. A., and Lanham J. L. (1987) Nitrogen isotopic ecology in southern Africa: implications for environmental and dietary tracing. Geochim. Cosmochim. Acta 51, 2707-2717.
Sheppard P. R., Comrie A. C., Packin G. D., Angersbach K., and Hughes M. K. (2002) The climate of the US Southwest. Clim. Res. 21, 219-238.

Smith K. F., Sharp Z. D., and Brown J. H. (2002) Isotopic composition of carbon and oxygen in desert fauna: investigations into the effects of diet, physiology, and seasonality. J. Arid Environ. 52, 419-430.

Sponheimer M., Robinson T., Ayliffe L., Passey B., Roeder B., Shipley L., Lopez E., Cerling T., Dearing D., and Ehleringer J. (2003) An experimental study of carbon-isotope fractionation between diet, hair, and faeces of mammalian herbivores. Can. $J$. Zool. 81, 871-876.

Stapp P., Polis G. A., and Sánchez Piñero F. (1999) Stable isotopes reveal strong marine and $\mathrm{El}$ Niño effects on island food webs. Nature 401, 467-469.

Sullivan J. C., Buscetta K. J., Michener R. H., Whitaker, Jr., J. O., Finnerty J. R., and Kunz T. H. (2006) Models developed from $\delta^{13} \mathrm{C}$ and $\delta^{15} \mathrm{~N}$ of skin tissue indicate non-specific habitat use by the big brown bat (Eptesicus fuscus). Ecoscience 13, 11-22.

Tieszen L. L., Reed B. C., Bliss N. B., Wylie B. K., and DeJong D. D. (1997) NDVI, $C_{3}$ and $C_{4}$ production, and distributions in Great Plains grassland land cover classes. Ecol. Appl. 7, 59-78.

Wang G., and Schimel D. (2003) Climate change, climate modes, and climate impacts. Annu. Rev. Environ. Resour. 28, 1-28.

Wassenaar L. I., and Hobson K. A. (1998) Natal origins of migratory monarch butterflies at wintering colonies in Mexico: new isotopic evidence. Proc. Natl. Acad. Sci. USA 95, 15436 15439.

Webb S. C., Hedges R. E. M., and Simpson S. J. (1998) Diet quality influences the $\delta^{13} \mathrm{C}$ and $\delta^{15} \mathrm{~N}$ of locusts and their biochemical components. J. Exp. Biol. 201, 2903-2911.

Weiss J. L., Gutzler D. S., Coonrod J. E. A., and Dahm C. N.

(2004) Seasonal and inter-annual relationships between vegetation and climate in central New Mexico, USA. J. Arid Environ. 57, 507-534.

West N. E. (1983) Overview of North American temperate deserts and semi-deserts. In Ecosystems of the World 5: temperate Deserts and Semi-deserts (ed. N. E. West) Elsevier, Amsterdam, pp. 321-330.

Wilkins K. T. (1989) Tadarida brasiliensis. Mammal. Species 331, $1-10$.

Williams Jr. C. N., Menne M. J., Vose R. S., and Easterling D. R. (2005) United States Historical Climatology Network Monthly Temperature and Precipitation Data. ORNL/CDIAC-118, NDP-019.

WRI (2002) World Resources Institute. Drylands, People, and Ecosystem Goods and Services: a Web-based Geospatial Analysis $<$ http://www.wri.org $>$.

Wright W. E., Long A., Comrie A. C., Leavitt S. W., Cavazos T., and Eastoe C. (2001) Monsoonal moisture sources revealed using temperature, precipitation, and precipitation stable isotope timeseries. Geophys. Res. Lett. 28, 787-790.

Associate editor: Jay A. Brandes 